\title{
Process and metabolic engineering perspectives of lactate production in mammalian cell cultures
}

DOI:

10.1016/j.coche.2018.10.004

https://doi.org/10.1016/j.coche.2018.10.004

\section{Document Version}

Accepted author manuscript

Link to publication record in Manchester Research Explorer

\section{Citation for published version (APA):}

Dickson, A., Torres Sebastian, M., \& Altamirano, C. (2018). Process and metabolic engineering perspectives of lactate production in mammalian cell cultures. Current Opinion in Chemical Engineering, 22, 184-190.

https://doi.org/10.1016/j.coche.2018.10.004, https://doi.org/10.1016/j.coche.2018.10.004

\section{Published in:}

Current Opinion in Chemical Engineering

\section{Citing this paper}

Please note that where the full-text provided on Manchester Research Explorer is the Author Accepted Manuscript or Proof version this may differ from the final Published version. If citing, it is advised that you check and use the publisher's definitive version.

\section{General rights}

Copyright and moral rights for the publications made accessible in the Research Explorer are retained by the authors and/or other copyright owners and it is a condition of accessing publications that users recognise and abide by the legal requirements associated with these rights.

\section{Takedown policy}

If you believe that this document breaches copyright please refer to the University of Manchester's Takedown Procedures [http://man.ac.uk/04Y6Bo] or contact uml.scholarlycommunications@manchester.ac.uk providing relevant details, so we can investigate your claim.

\section{OPEN ACCESS}




\section{Accepted Manuscript}

Title: Process and metabolic engineering perspectives of lactate production in mammalian cell cultures

Authors: Mauro Torres, Claudia Altamirano, Alan J. Dickson

PII: $\quad$ S2211-3398(18)30059-5

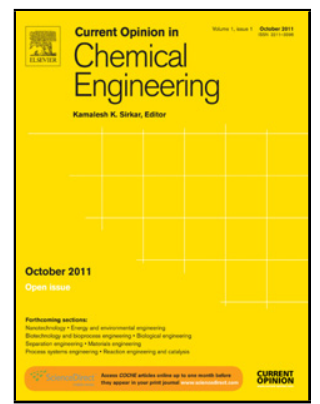

DOI: $\quad$ https://doi.org/10.1016/j.coche.2018.10.004

Reference: $\quad$ COCHE 492

To appear in:

Please cite this article as: Torres M, Altamirano C, Dickson AJ, Process and metabolic engineering perspectives of lactate production in mammalian cell cultures, Current Opinion in Chemical Engineering (2018), https://doi.org/10.1016/j.coche.2018.10.004

This is a PDF file of an unedited manuscript that has been accepted for publication. As a service to our customers we are providing this early version of the manuscript. The manuscript will undergo copyediting, typesetting, and review of the resulting proof before it is published in its final form. Please note that during the production process errors may be discovered which could affect the content, and all legal disclaimers that apply to the journal pertain. 
Review

\section{Process and metabolic engineering perspectives of lactate production in mammalian cell cultures}

Mauro Torres ${ }^{1}$, Claudia Altamirano ${ }^{2,3}$, Alan J. Dickson ${ }^{1}$

${ }^{1}$ Manchester Institute of Biotechnology, Faculty of Science and Engineering, University of Manchester, Manchester, UK

²School of Biochemical Engineering, Pontificia Universidad Católica de Valparaíso, Valparaíso, Chile

${ }^{3}$ Regional Center for Healthy Food Studies (CREAS) R17A10001, CONICYT REGIONAL, GORE Valparaiso, Chile.

Corresponding author: Prof. Alan J. Dickson

Correspondence should be addressed to AJD (email: alan.dickson@manchester.ac.uk)

\section{Graphical abstract}




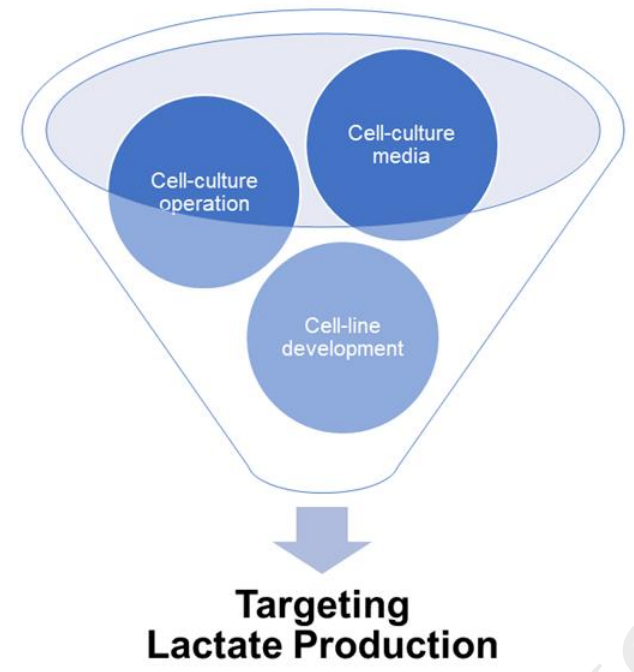

\section{Abstract}

Mammalian cells present the main expression platforms for production of recombinant therapeutic proteins. To cope with the increased demand for these therapeutics, more productive manufacturing processes have been developed using high-density cultures and enriched feeds/media. This has dramatically increased the productivity of mammalian cells in culture but this is accompanied by an increased production and accumulation of lactate in cultures, with the pattern of phasic production and consumption of lactate associated with the cell productivity in culture. Although primarily defined as a waste product, it is clear that lactate metabolism presents a control node for determination of process control and effectiveness of manufacturing strategies. This review focuses on recent understanding of the phasic nature of lactate metabolism, the impact of culture environment (media, feeds) on lactate metabolism, the link between lactate metabolic status and cell status and the culture/metabolic engineering approaches that have been applied to generate the lactate metabolic phenotype associated with a highly productive manufacturing process 


\section{Introduction}

In the last 30 years, major improvements in final product titres and viable cell density have been achieved in mammalian cell-based cultures with the upstream process optimisation (i.e., culture operation and tailor-made medium/feeds) [1]. Associated with the drive towards enhanced biomass, metabolic processing of enriched feeds has led to the accumulation of metabolic "waste" products that have consequences on the productivity and quality of therapeutic recombinant ( $r-)$ protein products. Great attention has been directed on production and accumulation of lactate in culture as a waste product but recent attention has illustrated that other metabolites can accumulate and become growth limitating to Chinese Hamster Ovary $(\mathrm{CHO})$ cells $[2,3]$. A recent review has focused on the molecular mechanisms through which lactate metabolism can be regulated [ $4^{*}$ ]. Here we direct attention to the manufacturing perspective and how lactate metabolism, and its potential as an indicator of process status, offers a model for understanding how it may prove possible to rationalise manufacture optimisation.

In $\mathrm{CHO}$ cell systems, lactate concentrations above $20 \mathrm{mM}$ diminish r-protein yield, whilst concentrations exceeding $40 \mathrm{mM}$ severely impair growth [5,6]. The implementation of large-scale fedbatch or perfusion operation using $\mathrm{CHO}$ cells has driven lactate accumulation above $80 \mathrm{mM}[7,8 *, 9]$ and maintenance of the optimal culture $\mathrm{pH}$ in bioreactors necessitates addition of high amounts of alkali. Addition of alkali, by increased osmolality, can inhibit cell growth and, additionally, lead to lower r-protein production [10]. A multivariate analysis of Genentech's manufacturing data highlighted lactate metabolism as a key parameter in determining final productivity of a process [11]. Similar conclusions have been generated by two other independent analyses with data from different manufacturing processes [12,13]. Hence, from a bioprocess perspective, restricting lactate production would aid the development of robust and productive therapeutic r-protein production and, at process and metabolic engineering levels, several strategies have been applied to reduce lactate formation and redirect lactate towards consumption (Figure 1). 


\section{Changing lactate metabolism through modification of culture environment}

Recent studies exploring the carbon flux distribution in industrially-relevant mammalian cell lines showed that that around $60-80 \%$ of glucose and $16-25 \%$ of glutamine are converted into lactate during the exponential phase $[12,13,14,15]$. The metabolism status of glucose and glutamine are a key determinant in the switch from lactate production to consumption, an event widely reported to occur when glucose or glutamine availability is limited $[5,16,17]$. A survey of several manufacturing runs at Genentech indicated that lactate consumption was a prominent factor in determining the productivity of r-proteins in production-scale cultures [11]. The profile of lactate metabolism is not solely down to glucose availability as lactate consumption has been reported even when there is appreciable amount of glucose in the culture medium [16-18]. Two independent studies observed that glutamine availability modulates lactate fate (either production or consumption) at the end of culture $[16,18]$ and a strong positive correlation was observed between the lactate and glutamine metabolism (after the metabolic shift) in $\mathrm{CHO}$ cells [18]. As the pattern of lactate metabolism is closely linked to glucose and glutamine metabolism, many of the strategies to develop a decreased lactate production phenotype are focused on the control of these two carbon sources.

Many different sugars, such as galactose, fructose, mannose or maltose, have been proposed as substitutes to glucose, offering the advantage of slower consumption than glucose in culture, leading to less lactate production. Substitution of glucose by galactose, for example, produced significantly less lactate but decreased specific cell growth rate and peak viable cell density [19]. To enhance cell biomass, a biphasic culture strategy (alternating the consumption of glucose and galactose) has been proposed in $\mathrm{CHO}$ cell batch and fed-batch cultures [20,21]. Using this strategy, high cell densities have been achieved with significantly decreased (up 66\%) lactate accumulation and improved galactosylation in fed-batch cultures [20-22]. Aternatives to glutamine (glutamate, pyruvate, TCA cycle intermediaries and dipeptides) have also been developed. Initially aimed at decreasing ammonia accumulation, these approaches have also impacted on the lactate formation. The use of glutamate, pyruvate or dipeptides such as L-alanyl-L-glutamine (commercially available as 
GlutaMAXTM) has proven to be reliable substitutes for glutamine and led to decreased lactate accumulation $\left[19,23,24^{\bullet}, 25,26\right]$. However, the replacement of glucose and glutamine eventually entails a large impact on glycosylation of therapeutic r-proteins $[27,28]$. Other medium additives can promote changes to lactate metabolism, although the mechanisms may not be clear. For example, the addition of copper promotes cell growth and r-protein production and decreases lactate formation in several mammalian cell lines [29-31]. However, its use often leads to unpredictable r-protein quality $[30,31]$.

Medium and feed design has been engineered to push the metabolic balance towards the lactate consumption phenotype. $\mathrm{Li}$ et al. designed a lactate containing feed to supply energy to cells whilst controlling culture $\mathrm{pH}$ [32]. Freund and Croughan (2018) recently reported a Lactate Supplementation and Adaptation (LSA) technology in which $\mathrm{CHO}$ cells were adapted to a lactate-supplemented medium which resulted in a near-minimal production of lactate [8*0. When applied to industrial fedbatch bioreactor cultures, LSA led to an 8-fold decrease in lactate production and a high viable cell concentration (around 35 million cells per $\mathrm{mL}$ ).

\section{Changing lactate metabolism through modification of process}

Dynamic feeding approaches have been used to maintain glucose and glutamine at very low concentrations to decrease lactate accumulation in industrial mammalian cell cultures $[5,7,29,33]$. Application of stoichiometric models or on-line oxygen uptake rate measurement have resulted in considerable decreased lactate accumulation and increased maximal viable cell density and final titre. Although successfully applied in laboratory-scale bioreactors in academia and industry with considerably decreased lactate accumulation in culture, there is no public information of implemention in large-scale mammalian cell cultures. Gagnon et al. proposed a pH-controlled feeding strategy called HI-end pH-controlled Delivery of Glucose (HiPDOG) [7]. Through continuous monitoring and control of residual glucose concentrations, lactate production was substantially decreased with increased product titres in mammalian cell cultures without the use of an external sensor system or frequent sample withdraw. To address the potential problem of failure to feedback control, Goldrick et al designed a highly robust and flexible method to maintain glucose at an adjustable set-point 
without the need of an external sensor [34]. This method has been successfully applied to varied scales (from $15 \mathrm{~mL}$ shake flasks to $50 \mathrm{~L}$ bioreactors) and cell lines with significantly varied glucose uptake rates. With the implementation of this methodology, cells underwent a lactate switch and depleted almost $100 \%$ of lactate produced during the lactate production phase.

Linear correlations have been observed between specific lactate production rate and the setpoints for $\mathrm{pH}$ and temperature in batch cultures [35]. Temperature decrease slows cell metabolism, with a decreased consumption of glucose and glutamine and production of lactate both in batch and fedbatch cultures $[36,37]$. In some studies, decreased culture temperature leads to lactate consumption $[17,18]$, in a cell line-dependent manner. Decreased culture $\mathrm{pH}$, via changes to the activity of glycolytic enzymes and membrane potential, is associated with decreased rates of specific glucose consumption and lactate production [38]. Several studies have shown that the metabolic switch from lactate production to lactate consumption in mammalian cells is dependent on the culture $\mathrm{pH}$ setpoint $[39,40]$. However, as both strategies influence cell growth, $r$-protein productivity and glycosylation adversely [41,42], the lactate metabolism are optimized on a case-by-case basis in biphasic cultures where these parameters are first controlled to setpoints which favor extensive cell proliferation prior to shifts to setpoints where lactate metabolism is modified [40].

\section{Changing lactate metabolism by metabolic engineering}

Regulating the expression of GLUT transporters in combination with the use of alternative carbon sources have been proposed to improve culture performance of recombinant mammalian cells. The most successful case has been the overexpression of the GLUT5 fructose-specific transporter with fructose as main carbon source in culture medium. This strategy led to a dramatic decrease in lactate production rates and an increase in viable cell density compared to glucose-based cultures, in human myeloma derived and $\mathrm{CHO}$ cell lines [43,44]. However, the consequence of overexpression of GLUT5 for lactate metabolism by recombinant cell lines depends to a large extent on the regulation of expression of the glut5 gene. To illustrate this, Le et al. [45] proposed a biphasic culture strategy using a GLUT5 dynamic expression system in concert with cell growth. This strategy enabled cells to consume fructose according to cellular needs rather than in excess as typically seen in culture, thus 
driving better cell growth, higher product titre and lower lactate production. Coversely, Wilkens and Gerdtzen using a constitutive GLUT5-overexpressing $\mathrm{CHO}$ cell line in a conventional batch with fructose as the main carbon source reported increased cell growth and IgG production, but similar lactate production compared to glucose-based cultures [46].

Prevention of activity of lactate dehydrogenase ( $\mathrm{LDH}-\mathrm{A})$ appears a direct strategy to decrease lactate production. Elimination of LDH-A by gene knock-out is lethal for mammalian cells [47*0]. Consequently, efforts have focused on knocking down (rather than knocking-out) LDH-A activity. Approaches, such as homologous recombination [48], antisense mRNA expression technology $[49,50]$ or small interfering RNA (siRNA) [51], have been shown to decrease LDH-A activity to different degrees. Such modification has led to decreased lactate production and improved cell growth in recombinant hybridoma and $\mathrm{CHO}$ cell lines. However, decreasing LDH-A activity had mixed results for carbon metabolism and r-protein production. Suppression of LDH-A activity has been combined with modulation of the expression of other proteins that might be associated with improved cellular phenotype. This includes overexpression of the anti-apoptotic protein $\mathrm{Bcl}-2$ [52] and the downregulation of pyruvate dehydrogenase kinases (PDHKs) (i.e. PDHK1, 2 and 3) [53] in CHO cells. By applying these strategies, cell cultures dramatically decreased lactate accumulutation (by up to $90 \%$ ) and increased r-protein production. The supplementation of $\mathrm{CHO}$ cell cultures with dichloroacetate (DCA), an inhibitor of PDHK, decreased lactate production, increased viable cell density and final antibody titre $\left[4^{\circ 0^{\circ}}\right.$ ], supporting gene-level approaches that PDHK are relevant metabolic targets to develop cell factories with improved culture performance. Recently, Noh et al downregulated LDH-A expression in host and a recombinant $\mathrm{CHO}$ cell lines with the GS selection system [54*]. The downregulation of $\mathrm{LDH}-\mathrm{A}$ in the recombinant $\mathrm{CHO}$ cell line decreased lactate production and improved N-glycosylation. However, this strategy could not be applied to host cell lines because it hampered the selection process of the glutamine synthetase system [54]. In a novel approach, Fu et al. developed a lactate-tolerant $\mathrm{CHO}$ cell line by overexpressing lactate dehydrogenase $\mathrm{C}$ (LDH-C) that led to improved cell growth, decreased lactate production and a more robust apoptosis response in $\mathrm{CHO}$ cells [6]. Although this strategy has been only tested in a specific $\mathrm{CHO}$ cell line, $\mathrm{LDH}-\mathrm{C}$ 
emerges as an interesting engineering approach for generating host cell lines with better r-protein yield and quality.

As an extension to redirection of pyruvate away from lactate formation, the potential consequence of increasing pyruvate oxidation in mitochondria has been examined in mammalian cell cultures. Overexpression of anaplerotic enzymes, such as pyruvate carboxylase (PC) or malate dehydrogenase $(\mathrm{MDH})$ offer the potential to "pull" pyruvate from a lactate production fate. Many reports have shown that overexpression of cytosolic yeast PC (PYC2) effectively decreases lactate production, improves cell viability and leads to a more efficient use of the carbon sources in recombinant HEK293, BHK-21 and $\mathrm{CHO}$ cell lines $\left[24^{\bullet}, 55-57\right] .$. However, there are mixed results with respect to r-protein production, glucose consumption and the capacity of cells to shift from a lactate-producing to lactate-consuming phenotype. Most recent studies have highlighted the relevance of upstream process development, particularly the influence that clonal variation and culture process have on the outcoming productivity and nutrient consumption levels of PYC2 expressing cell lines.

Further strategies have been developed to screen and isolate clones with desired metabolic features and production capacity. Gupta et al. [58] implemented a dual selection strategy to select clones based on expression of PYC2 mRNA. With this methodology, they isolated clones that attain an extended fed-batch process with very high cell density, high glucose consumption rate, and significantly decreased lactate production. In a different approach, Toussaint et al. [56] generated a PYC2-expressing $\mathrm{CHO}$ cell line and isolated 3 clones with high PYC2 protein expression. All isolated clones presented improved cell growth, r-protein production and a decreased lactate accumulation with a clear metabolic shift towards lactate consumption, both in batch and fed-batch with different culture media. In contrast, studies using polyclonal populations of PYC2-expressing $\mathrm{CHO}$ cells (with varying expression of PYC2) showed inconsistent results of in terms of cell growth and productivity, despite an evident decrease in lactate production. PYC2 overexpression in HEK293 and CHO cells dramatically impacted upon the improvement of cell metabolism and r-protein production even under controlled bioreactors culture conditions with optimised medium/feeds composition $\left[24^{\bullet}, 55-57\right]$. 
Overexpression of malate dehydrogenase II (MDH II) has been also proposed as a strategy to overcome a TCA cycle bottleneck and improve energy metabolism in $\mathrm{CHO}$ cells $[46,59]$. These two independent reports developed $\mathrm{MDH}$ II-overexpressing $\mathrm{CHO}$ cell lines with significantly decreased lactate production and decreased the NAD+/NADH ratio but with contradictory results on the value to MDH II as a target to enhance cell growth.

\section{Concluding comments and future perspectives}

The increased understanding of lactate metabolism has made it possible to develop strategies that decrease lactate accumulation in cultures. Lactate produced during the culture processes of mammalian cells is regarded as a waste product that is detrimental to efficient cell performance and development of the manufacturing platform. Yet this view is arguably too simplistic. Under specific metabolic (or culture phase) conditions cells can use lactate to provide part of the metabolic input that is associated with prolongment of culture or enhanced production of recombinant proteins. From a manufacturing perspective, lactate production (associated with rapid cell growth during exponential culture phase) is valuable if subsequent consumption of lactate can be built into the cell culture process. Combination of process and metabolic engineering offers a promising approach to generate an effective balance of a limited early lactate production and subsequent lactate consumption. For instance, the overexpression of PYC2 combined with a rational feed design has proven to be a successful approach for the development of high-titre fed-batch cultures with a consistently advantageous profile of lactate metabolism in different industrially-relevant mammalian cell lines [5658]. Selection of clones with a desirable lactate metabolic profile (low-producing/high-consuming phenotype) offers a route to an better overall metabolic phenotype. However, the lactate-consuming phenotypehas been reported to be lost due to unknown factors for certain clones, even in validated cGMP processes making commercial products [11], and such a selection criterion may increase the chances of discarding good production clones.

Ultimately, the question remains open: is it possible to develop a universal and reliable method to generate metabolically super-efficient cell lines that produce high titres in culture? In the opinion of these reviewers, metabolic engineering approaches are still unreliable compared to control process 
engineering strategies such as those proposed by Gagnon et al [7], Freund and Croughan [8*0] and Goldrick et al. [34ㄹ that have realised the potential to gain the benefits of altered lactate production in large-scale manufacturing processes.

The authors declare no conflicts of interest 


\section{References}

[1] A.J. Dickson, Enhancement of production of protein biopharmaceuticals by mammalian cell cultures: The metabolomics perspective, Curr. Opin. Biotechnol. 30 (2014) 73-79. doi:10.1016/j.copbio.2014.06.004.

[2] B.C. Mulukutla, J. Kale, T. Kalomeris, M. Jacobs, G.W. Hiller, Identification and control of novel growth inhibitors in fed-batch cultures of Chinese hamster ovary cells, Biotechnol. Bioeng. 114 (2017) 1779-1790. doi:10.1002/bit.26313.

[3] S. Pereira, H.F. Kildegaard, M.R. Andersen, Impact of CHO Metabolism on Cell Growth and Protein Production: An Overview of Toxic and Inhibiting Metabolites and Nutrients, Biotechnol. J. 13 (2018) 1-13. doi:10.1002/biot.201700499.

[4] F. Hartley, T. Walker, V. Chung, K. Morten, Mechanisms driving the lactate switch in Chinese hamster ovary cells, Biotechnol. Bioeng. 115 (2018) 1890-1903. doi:10.1002/bit.26603.

- An excellent mechanistic review of molecular details of lactate handling by $\mathrm{CHO}$ cells

[5] N. Ma, J. Ellet, C. Okediadi, P. Hermes, E. McCormick, S. Casnocha, A single nutrient feed supports both chemically defined NSO and CHO fed-batch processes: Improved productivity and lactate metabolism, Biotechnol. Prog. 25 (2009) 1353-1363. doi:10.1002/btpr.238.

[6] T. Fu, C. Zhang, Y. Jing, C. Jiang, Z. Li, S. Wang, K. Ma, D. Zhang, S. Hou, J. Dai, G. Kou, H. Wang, Regulation of cell growth and apoptosis through lactate dehydrogenase C overexpression in Chinese hamster ovary cells, Appl. Microbiol. Biotechnol. 100 (2016) 50075016. doi:10.1007/s00253-016-7348-4.

[7] M. Gagnon, G. Hiller, Y.T. Luan, A. Kittredge, J. Defelice, D. Drapeau, High-End pHcontrolled delivery of glucose effectively suppresses lactate accumulation in $\mathrm{CHO}$ Fed-batch cultures, Biotechnol. Bioeng. 108 (2011) 1328-1337. doi:10.1002/bit.23072.

[8] N.W. Freund, M.S. Croughan, A simple method to reduce both lactic acid and ammonium 
production in industrial animal cell culture, Int. J. Mol. Sci. 19 (2018) 385. doi:10.3390/ijms19020385.

- $\mathrm{CHO}$ cells adapted to growth in lactate-supplemented medium exhibit greatly diminished production of lactate and ammonia, associated with high cell density achievement

[9] Y. Zhang, P. Stobbe, C.O. Silvander, V. Chotteau, Very high cell density perfusion of $\mathrm{CHO}$ cells anchored in a non-woven matrix-based bioreactor, J. Biotechnol. 213 (2015) 28-41. doi:10.1016/j.jbiotec.2015.07.006.

[10] H.J. Cruz, C.M. Freitas, P.M. Alves, J.L. Moreira, M.J.T. Carrondo, Effects of ammonia and lactate on growth, metabolism, and productivity of BHK cells, Enzyme Microb. Technol. (2000). doi:10.1016/S0141-0229(00)00151-4.

[11] H. Le, S. Kabbur, L. Pollastrini, Z. Sun, K. Mills, K. Johnson, G. Karypis, W.S. Hu, Multivariate analysis of cell culture bioprocess data-Lactate consumption as process indicator, J. Biotechnol. 162 (2012) 210-223. doi:10.1016/j.jbiotec.2012.08.021.

[12] S. Charaniya, H. Le, H. Rangwala, K. Mills, K. Johnson, G. Karypis, W.S. Hu, Mining manufacturing data for discovery of high productivity process characteristics, J. Biotechnol. 147 (2010) 186-197. doi:10.1016/j.jbiotec.2010.04.005.

[13] A.O. Kirdar, K.D. Green, A.S. Rathore, Application of multivariate data analysis for identification and successful resolution of a root cause for a bioprocessing application, Biotechnol. Prog. 24 (2008) 720-726. doi:10.1021/bp0704384.

[14] J. Dean, P. Reddy, Metabolic analysis of antibody producing CHO cells in fed-batch production, Biotechnol. Bioeng. 110 (2013) 1735-1747. doi:10.1002/bit.24826.

[15] J.D. Young, Metabolic flux rewiring in mammalian cell cultures, Curr. Opin. Biotechnol. 24 (2013) 1108-1115. doi:10.1016/j.copbio.2013.04.016.

[16] F. Zagari, M. Jordan, M. Stettler, H. Broly, F.M. Wurm, Lactate metabolism shift in CHO cell culture: The role of mitochondrial oxidative activity, N. Biotechnol. 30 (2013) 238-245. 
doi:10.1016/j.nbt.2012.05.021.

[17] R.P. Nolan, K. Lee, Dynamic model of CHO cell metabolism, Metab. Eng. 13 (2011) 108124. doi:10.1016/j.ymben.2010.09.003.

[18] M. Torres, R. Zúñiga, M. Gutierrez, M. Vergara, N. Collazo, J. Reyes, J. Berrios, J.C. Aguillon, M.C. Molina, C. Altamirano, Mild hypothermia upregulates myc and xbp1s expression and improves anti-TNFa production in CHO cells, PLoS One. 13 (2018) e0194510. doi:10.1371/journal.pone.0194510.

[19] C. Altamirano, C. Paredes, J.J. Cairó, F. Gòdia, Improvement of CHO cell culture medium formulation: Simultaneous substitution of glucose and glutamine, Biotechnol. Prog. 16 (2000) 69-75. doi:10.1021/bp990124j.

[20] Y. Sun, L. Zhao, Z. Ye, L. Fan, X. ping Liu, W.S. Tan, Development of a fed-batch cultivation for antibody-producing cells based on combined feeding strategy of glucose and galactose, Biochem. Eng. J. 81 (2013) 126-135. doi:10.1016/j.bej.2013.10.012.

[21] J. Liu, J. Wang, L. Fan, X. Chen, D. Hu, X. Deng, H. Fai Poon, H. Wang, X. Liu, W.S. Tan, Galactose supplementation enhance sialylation of recombinant $\mathrm{Fc}$-fusion protein in $\mathrm{CHO}$ cell: an insight into the role of galactosylation in sialylation, World J. Microbiol. Biotechnol. 31 (2015) 1147-1156. doi:10.1007/s11274-015-1864-8.

[22] C. Altamirano, C. Paredes, A. Illanes, J.J. Cairó, F. Gòdia, Strategies for fed-batch cultivation of t-PA producing $\mathrm{CHO}$ cells: Substitution of glucose and glutamine and rational design of culture medium, J. Biotechnol. 110 (2004) 171-179. doi:10.1016/j.jbiotec.2004.02.004.

[23] T.K. Ha, G.M. Lee, Effect of glutamine substitution by TCA cycle intermediates on the production and sialylation of Fc-fusion protein in Chinese hamster ovary cell culture, J. Biotechnol. 180 (2014) 23-29. doi:10.1016/j.jbiotec.2014.04.002.

[24] E. Karengera, Y. Durocher, G. De Crescenzo, O. Henry, Combining metabolic and process 
engineering strategies to improve recombinant glycoprotein production and quality, Appl. Microbiol. Biotechnol. 101 (2017) 7837-7851. doi:10.1007/s00253-017-8513-0.

- Engineering HEK293 cells to over-express yeats pyruvate carboxylase decreased lactate production and increased recombinant IFN $\alpha 2 b$ expression

[25] M.P. Gillmeister, N. Tomiya, S.J. Jacobia, Y.C. Lee, S.F. Gorfien, M.J. Betenbaugh, An HPLC-MALDI MS method for N-glycan analyses using smaller size samples: Application to monitor glycan modulation by medium conditions, Glycoconj. J. (2009). doi:10.1007/s10719009-9235-z.

[26] Y. Imamoto, H. Tanaka, K. Takahashi, Y. Konno, T. Suzawa, Advantages of AlaGln as an additive to cell culture medium: Use with anti-CD20 chimeric antibody-producing POTELLIGENTTM CHO cell lines, Cytotechnology. (2013). doi:10.1007/s10616-012-9468-8.

[27] J. Berrios, C. Altamirano, N. Osses, R. Gonzalez, Continuous CHO cell cultures with improved recombinant protein productivity by using mannose as carbon source: Metabolic analysis and scale-up simulation, Chem. Eng. Sci. 66 (2011) 2431-2439. doi:10.1016/j.ces.2011.03.011.

[28] T.K. Ha, M. Lee, Glutamine substitution : the role it can play to enhance therapeutic protein production, Pharm. Bioprocess. 3 (2015) 249-261. doi:10.4155/PBP.15.6.

[29] J. Luo, N. Vijayasankaran, J. Autsen, R. Santuray, T. Hudson, A. Amanullah, F. Li, Comparative metabolite analysis to understand lactate metabolism shift in Chinese hamster ovary cell culture process, Biotechnol. Bioeng. 109 (2012) 146-156. doi:10.1002/bit.23291.

[30] Y. Qian, S.F. Khattak, Z. Xing, A. He, P.S. Kayne, N.X. Qian, S.H. Pan, Z.J. Li, Cell culture and gene transcription effects of copper sulfate on Chinese hamster ovary cells, Biotechnol. Prog. 27 (2011) 1190-1194. doi:10.1002/btpr.630.

[31] I.H. Yuk, S. Russell, Y. Tang, W.T. Hsu, J.B. Mauger, R.P.S. Aulakh, J. Luo, M. Gawlitzek, J.C. Joly, Effects of copper on $\mathrm{CHO}$ cells: Cellular requirements and product quality 
considerations, Biotechnol. Prog. 31 (2015) 226-238. doi:10.1002/btpr.2004.

[32] J. Li, C.L. Wong, N. Vijayasankaran, T. Hudson, A. Amanullah, Feeding lactate for $\mathrm{CHO}$ cell culture processes: Impact on culture metabolism and performance, Biotechnol. Bioeng. 109 (2012) 1173-1186. doi:10.1002/bit.24389.

[33] W. Zhou, J. Rehm, A. Europa, W.S. Hu, Alteration of mammalian cell metabolism by dynamic nutrient feeding, Cytotechnology. 24 (1997) 99-108. doi:10.1023/A:1007945826228.

[34] S. Goldrick, K. Lee, C. Spencer, W. Holmes, M. Kuiper, R. Turner, S.S. Farid, On-Line Control of Glucose Concentration in High-Yielding Mammalian Cell Cultures Enabled Through Oxygen Transfer Rate Measurements, Biotechnol. J. 13 (2018). doi:10.1002/biot.201700607.

- Development of an on-line process control strategy to modulate glucose use (and lactate production) from micro- to pilot-scale systems

[35] S.J. Hwang, S.K. Yoon, G.Y. Koh, G.M. Lee, Effects of culture temperature and pH on flagtagged COMP angiopoietin-1 (FCA1) production from recombinant $\mathrm{CHO}$ cells: FCA1 aggregation, Appl. Microbiol. Biotechnol. (2011). doi:10.1007/s00253-011-3266-7.

[36] S.K. Yoon, J.Y. Song, G.M. Lee, Effect of low culture temperature on specific productivity, transcription level, and heterogeneity of erythropoietin in Chinese hamster ovary cells, Biotechnol. Bioeng. 82 (2003) 289-298. doi:10.1002/bit.10566.

[37] S.N. Sou, K. Lee, K. Nayyar, K.M. Polizzi, C. Sellick, C. Kontoravdi, Exploring cellular behaviour under transient gene expression and its impact on mAb productivity and Fcglycosylation, Biotechnol. Bioeng. (2017) 1-7. doi:10.1002/bit.26456.

[38] S.K. Yoon, S.H. Kim, J.Y. Song, G.M. Lee, Biphasic culture strategy for enhancing volumetric erythropoietin productivity of Chinese hamster ovary cells, Enzyme Microb. Technol. (2006). doi:10.1016/j.enzmictec.2005.11.029. 
[39] L. Liste-Calleja, M. Lecina, J. Lopez-Repullo, J. Albiol, C. Solà, J.J. Cairó, Lactate and glucose concomitant consumption as a self-regulated $\mathrm{pH}$ detoxification mechanism in HEK293 cell cultures, Appl. Microbiol. Biotechnol. 99 (2015) 9951-9960.

doi:10.1007/s00253-015-6855-z.

[40] D. Zalai, K. Koczka, L. Párta, P. Wechselberger, T. Klein, C. Herwig, Combining mechanistic and data-driven approaches to gain process knowledge on the control of the metabolic shift to lactate uptake in a fed-batch CHO process, Biotechnol. Prog. 31 (2015) 1657-1668. doi:10.1002/btpr.2179.

[41] N. Gomez, J. Ouyang, M.D.H. Nguyen, A.R. Vinson, A.A. Lin, I.H. Yuk, Effect of temperature, $\mathrm{pH}$, dissolved oxygen, and hydrolysate on the formation of triple light chain antibodies in cell culture., Biotechnol. Prog. 26 (2010) 1438-1445. doi:10.1002/btpr.465.

[42] M. Ivarsson, T.K. Villiger, M. Morbidelli, M. Soos, Evaluating the impact of cell culture process parameters on monoclonal antibody N-glycosylation, J. Biotechnol. (2014). doi:10.1016/j.jbiotec.2014.08.026.

[43] Y. Inoue, Y. Tsukamoto, M. Yamanaka, S. Nakamura, A. Inoue, N. Nishino, H. Kawahara, Efficient production of recombinant IgG by metabolic control and co-expression with GLUT5 in a fructose-based medium, Cytotechnology. 62 (2010) 301-306. doi:10.1007/s10616-0109289-6.

[44] K.F. Wlaschin, W.S. Hu, Engineering cell metabolism for high-density cell culture via manipulation of sugar transport, J. Biotechnol. 131 (2007) 168-176. doi:10.1016/j.jbiotec.2007.06.006.

[45] H. Le, N. Vishwanathan, A. Kantardjieff, I. Doo, M. Srienc, X. Zheng, N. Somia, W. Hu, Dynamic gene expression for metabolic engineering of mammalian cells in culture, Metab. Eng. 20 (2013) 212-220. doi:10.1016/j.ymben.2013.09.004.

[46] C.A. Wilkens, Z.P. Gerdtzen, Comparative metabolic analysis of $\mathrm{CHO}$ cell clones obtained through cell engineering, for IgG productivity, growth and cell longevity, PLoS One. 10 
(2015) 1-15. doi:10.1371/journal.pone.0119053.

[47] M. Buchsteiner, L.-E. Quek, P. Gray, L.K. Nielsen, Improving culture performance and antibody production in $\mathrm{CHO}$ cell culture processes by reducing the Warburg effect, Biotechnol. Bioeng. (2018). doi:10.1002/bit.26724.

- Inhibition of pyruvate dehydrogenase kinase with dichloroacatetate increases viable cell density, culture lifespan and recombinant antibody production in $\mathrm{CHO}$ cells. Metabolite indicated that glucose weas redirected to more efficient use

[48] K. Chen, Q. Liu, L. Xie, P.A. Sharp, D.I.C. Wang, Engineering of a mammalian cell line for reduction of lactate formation and high monoclonal antibody production, Biotechnol. Bioeng. 72 (2001) 55-61. doi:10.1002/1097-0290(20010105)72:1<55::AID-BIT8>3.0.CO;2-4.

[49] D. Jeong, T.S. Kim, J.W. Lee, K.T. Kim, H.J. Kim, I. Kim, I.Y. Kim, Blocking of AcidosisMediated Apoptosis by a Reduction of Lactate Dehydrogenase Activity through Antisense mRNA Expression, Biochem. Biophys. Res. Commun. 1149 (2001) 1141-1149. doi:10.1006/bbrc.2001.6091.

[50] D. Jeong, I.T. Cho, T.S. Kim, G.W. Bae, I. Kim, I.Y. Kim, Effects of lactate dehydrogenase suppression and glycerol-3-phosphate dehydrogenase overexpression on cellular metabolism, Mol. Cell. Biochem. (2006) 1-8. doi:10.1007/s11010-005-9004-7.

[51] S.H. Kim, G.M. Lee, Down-regulation of lactate dehydrogenase-A by siRNAs for reduced lactic acid formation of Chinese hamster ovary cells producing thrombopoietin, Appl. Microbiol. Biotechnol. 74 (2007) 152-159. doi:10.1007/s00253-006-0654-5.

[52] M.K. Jeon, D.Y. Yu, G.M. Lee, Combinatorial engineering of ldh-a and bcl-2 for reducing lactate production and improving cell growth in dihydrofolate reductase-deficient Chinese hamster ovary cells, Appl. Microbiol. Biotechnol. 92 (2011) 779-790. doi:10.1007/s00253011-3475-0.

[53] M. Zhou, Y. Crawford, D. Ng, J. Tung, A.F.J. Pynn, A. Meier, I.H. Yuk, N. Vijayasankaran, K. 
Leach, J. Joly, B. Snedecor, A. Shen, Decreasing lactate level and increasing antibody production in Chinese Hamster Ovary cells $(\mathrm{CHO})$ by reducing the expression of lactate dehydrogenase and pyruvate dehydrogenase kinases, J. Biotechnol. 153 (2011) 27-34. doi:10.1016/j.jbiotec.2011.03.003.

[54] S.M. Noh, J.H. Park, M.S. Lim, J.W. Kim, G.M. Lee, Reduction of ammonia and lactate through the coupling of glutamine synthetase selection and downregulation of lactate dehydrogenase-A in CHO cells, Appl. Microbiol. Biotechnol. 101 (2017) 1035-1045. doi:10.1007/s00253-016-7876-y.

- Downregulation of lactate dehydrogenase- $\mathrm{A}$ in $\mathrm{CHO}$ cells is metabolically incompatible with the selection processes in GS-negative host cell lines

[55] E. Karengera, A. Robotham, J. Kelly, Y. Durocher, G. De Crescenzo, O. Henry, Altering the central carbon metabolism of HEK293 cells: Impact on recombinant glycoprotein quality, J. Biotechnol. 242 (2017) 73-82. doi:10.1016/j.jbiotec.2016.12.003.

[56] C. Toussaint, O. Henry, Y. Durocher, Metabolic engineering of $\mathrm{CHO}$ cells to alter lactate metabolism during fed-batch cultures, J. Biotechnol. 217 (2016) 122-131. doi:10.1016/j.jbiotec.2015.11.010.

[57] C. Vallée, Y. Durocher, O. Henry, Exploiting the metabolism of PYC expressing HEK293 cells in fed-batch cultures, J. Biotechnol. 169 (2014) 63-70. doi:10.1016/j.jbiotec.2013.11.002.

[58] S.K. Gupta, S.K. Srivastava, A. Sharma, V.H.H. Nalage, D. Salvi, H. Kushwaha, N.B. Chitnis, P. Shukla, Metabolic engineering of $\mathrm{CHO}$ cells for the development of a robust protein production platform, PLoS One. 12 (2017) e0181455. doi:10.1371/journal.pone.0181455.

[59] W.P.K. Chong, S.G. Reddy, F.N.K. Yusufi, D.Y. Lee, N.S.C. Wong, C.K. Heng, M.G.S. Yap, Y.S. Ho, Metabolomics-driven approach for the improvement of Chinese hamster ovary cell growth: Overexpression of malate dehydrogenase II, J. Biotechnol. 147 (2010) 116-121. 
doi:10.1016/j.jbiotec.2010.03.018. 
Fig 1
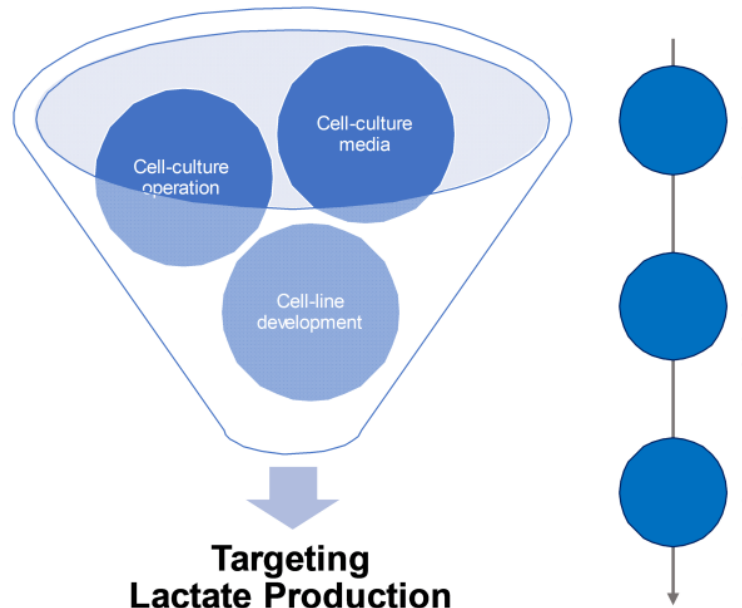

\section{Cell-culture media}

Interaction of glucose \& glutamine with lactate metabolism.

- Optimization of medium/feeds formulation.

Targeting Lactate Production

Cell-culture operation

- Feeding regimes strategies.

On-line control of culture parameters

- Environmental conditions (e.g., temperature or pH).

Cell-line development

- Overexpression, knock-in/-out of key metabolic enzyme or nutrient transporters. 